\title{
The formation of heroes and the myth of national identity
}

This paper discusses sports hero formation in relation to national identity, arguing that it can be a critical component of the development of a hero. A netnographic approach, that encompassed a number of virtual spaces and methods of analyses, was utilised to examine the formation of sports heroes within the setting of a new professional sports team. Drawing upon the work of Joseph Campbell and Orrin E. Klapp, it contextualises the sporting hero in the wider narratives of hero typologies. It argues that the formation of sports heroes is shaped by established notions of national identity and longstanding mythological archetypes rather than heroes' personal traits or deeds. Universal hero myths, furtherıore, provide recognised narratives that frame the emergence of new heroes in otherwise very different societies.

Keywords: Sport, heroes, national identity, mythology hero formation

\section{Introduction - How heroic is it to kick a ball?}

"We all need people to look up to. When you know yours, break down what it is you most admire about them" (Adam Goodes 2014)

It can be questioned whether athletes can or should be considered heroic (Wagg 2007). Indeed, Boorstin (1992) contended that warfare was the only source of heroes in the twentieth century but sport, famously described as 'war minus the shooting' by George Orwell (Beck 2013), has come to be a significant source of heroes, particularly in Australia (Donoghue \& Tranter 2018). The feats of top athletes are reproduced repeatedly by the mass media, making them seem increasingly spectacular and miraculous; the result of some sporting genius. Yet, while this media coverage increases the 'well-knownness' of the athletes, and their celebrity profile, a focus on their feats alone is not enough to explain the process of heroisation. Sport remains one of the key 
domains from which people, both young and old and from many societies, draw their heroes (Wann et al. 2001; Parry 2009). Therefore, to understand heroes, and the cultures that form them, one must turn to sport. While it has been argued that national identity is influenced by heroic sports figures (Allen 2013; Donoghue \& Tranter 2018), the influence of national identity on heroisation is less well understood.

If one was to ask most sports fans who their sporting hero is, it is likely that a name would be quickly offered. For fans, no explanation is needed for what a sports hero is, as the concept is deeply ingrained within sport. While fans may be able to offer some basic explanation for their choice of hero through, for instance, reference to the skill of the athlete or their pro-social behaviour (Parry 2009; Bifulco \& Tirino 2018), they may not follow the advice of 2014 Australian of the Year and former Sydney Swans Australian football player Adam Goodes and really "break down" what is important in their selection of a hero. This paper develops our understanding of the process by which heroes are formed and the role that national identity plays in this formation.

\section{Surveying the field}

The term hero is derived from the Greek heros and refers to one that is part human and part divine, transcending the mortal and the mundane (Boon 2005). While it may not be the case that modern heroes are explicitly presented as divine beings, top athletes are often believed to have seemingly superhuman powers that are greater than those of most mortals. Since the mid-twentieth century, sport has been increasingly commodified and now the faces of the top athletes are even known to those with little interest in sport (Smart 2007) and they are often heralded as heroes by their fans. Athletes who, for instance, set records for running faster than anyone has ever run before (Tännsjö 1998) 
offer the illusion of transcending the mortal, which partially serves to explain their heroisation. In discussing the sociology of sport, Maguire $(2011,854)$ argues that "[o]ur heroes express both the myths and revered social values of a society and the sports ethic...[which underpins] involvement in sport." Hartman (2014) contends that the myth of the sports hero is so strong that it can withstand any tears in its fabric or threats to its strength that result from athlete transgressions. She argues that the hero myth "will maintain power and continue to shape how we view athletes and sport" $(2014,166)$, and it, therefore, plays an important role in identity construction. Crepeau (1981, 24) also shares this view that heroes provide an insight into the society within which they are constructed, he suggests that heroes "show us what we ought to be, and we make him a hero because we wish to be what he is".

Despite the important social and cultural role that sports heroes play, particularly as a key component within sport consumption (Crawford 2004; Meân, Kassing \& Sanderson 2010), research in this area is limited and Greenwood and Casper (2006) identify the need for more research into this element of cultural consumption. A sociological understanding of heroes is therefore important.

While there is a body of sociological work that discusses celebrities, in both a sport context and more generally (Rojek 2001; Rojek 2012), this literature fails adequately to address the notion of sports heroes. The limited sociological literature that does exist on sports heroes (see Cashmore, 2004 or Smart, 2005) has tended to explain those who have emerged largely as a result of their sporting achievements or moral and physical superiority. Although there have been a number of studies that have focussed on analyses of established, and often departed, sporting heroes, examining the historical and cultural contexts for their heroisation (Hutchins 2002; Bale 2006; Phillips \& Osmond 2009; Naha 2012; Viita 2012; Allen 2013), most studies of sports heroes have 
widely utilised a social psychological approach to discover which athletes are identified as heroes (Wann et al. 2001; Stevens, Lathrop \& Bradish 2009; Sullivan \& Venter 2010). Such approaches, and social psychologists themselves, claim that individuals are free to make their own choices of heroes, primarily basing their choice on the personal characteristics of particular athletes. In contrast, sociologist Orrin E. Klapp (1948) contends that the personal traits of heroes are unimportant; for him the sociallyacceptable deeds that heroes perform are more significant. However, heroes cannot be considered to be solely an individual's decision. Individual fans may believe themselves 'free' to choose their hero, but they may not have the 'power' to create a hero (Crawford, 2004). Rather, it is a complex, interrelated network of social, cultural, historical, and political factors, and the media, that influences hero choices. These contexts explain the large degrees of similarity between the heroes chosen in a particular society.

There are several classic works that have presented shared characteristics of heroes and a number of archetypal forms that heroes can take. Such archetypes include categories such as the clever hero (Klapp 1954a), the prophet (Carlyle 1840), and the unpromising hero (Klapp 1948). In most instances, it is possible to identify a pattern in the 'journey' that heroes follow (Carlyle 1840), or in their life story (Raglan 1956). Campbell (2004), in particular, drew attention to the significance and frequency of this journey in hero tales, dubbing it the monomyth. The existence and enduring popularity of such typologies suggests that there is a degree of commonality in these choices. Durkheim (1965) argued that social phenomena are defined by the collective aspects of the beliefs and practices of the individuals - social facts - that make up a particular society as a reality that is 'sui generis' (distinct). In such a situation, memorable entities become sedimented in the collective unconscious of a society (Berger \& Luckman 
1966). Therefore, while the social psychological approach adopted in previous studies may have presented some explanation of the justifications that people present to explain their choice of hero, and for the differing categories of hero that may or may not exist, it is not used here. The apparent pseudo-religious nature of sports fandom and sports hero worship suggests that there are deeper societal issues at play within the lives of sports fans that cannot be explained by a social psychological investigation. Such approaches fail to address appropriately the social and cultural contexts within which people make decisions. While Sullivan and Venter (2010), as noted, allude tothe importance of the shared cultural background of the participants in their study, they failed adequately to consider what this cultural setting was and how it influenced their participants.

\section{Heroic tales}

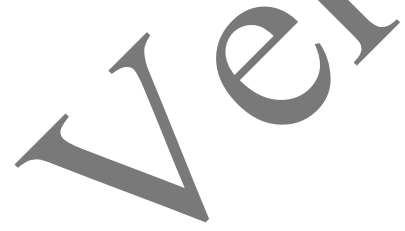

As noted above, Boorstin (1992) believed that acts performed on a battlefield were easily comprehended as heroic. In past eras, the accomplishments of the 'Big' (or 'Great') Men have been relatively easy to understand; explorers discovered new lands, artists created stunning works, political leaders fought for the rights of the people. He proposed that, as humanity progressed and became more scientific and technologically sophisticated, it was increasingly difficult to understand the achievements of the 'Big Men' of the times, whose achievements were accomplished on 'unintelligible frontiers'. Regardless of the basis for heroisation, Carlyle $(1840,26)$, in one of the classic studies into heroes, claims that all societies are a representation of a "graduated worship of heroes" and, for over four thousand years, tales around heroism have been reproduced in mythical formats (Campbell 2004), historically passed down through oral traditions to be told and retold until the hero myth has become ingrained in western society (Drucker \& Cathcart 1994). The significance of myths in earlier oral societies and 
twenty-first century life is emphasised by Berger and Luckman (1966) who argue that myths are among the most archaic of human constructions. These mythical stories have become everlasting, universally recognised structures (Lévi-Strauss 1955) that allow humans to make sense of both their lives and the world around them, living out the patterns of stories that have been previously created (Pearson 1989; Wright 2005). Such is 'our' reliance on stories and narratives that humans have been described as 'homo narrans' -the storytelling man (Fisher 1984). The media have assumed the ancient role of the storyteller in oral cultures to disseminate the stories surrounding heroes (Cathcart 1994).

Crepeau (1981) argues that sports heroes play a significant role in society as they are the purveyors of myths of national identity and speak to the fundamental character and concerns of the culture". In this manner they have the ability to represent the nation (or a particular society) and its ideals, which in turn helps to boost national pride. To be representative of a society Hutchins $(2005,29)$ discusses the need for heroes to:

...tap a vein of populist sentiment and appeal to ideals of national and/or regional character, and in doing so capture the popular and historical imagination.

\section{National Identity}

National identity is linked to "particularistic configurations of ethnic cores, myths and memories, religious beliefs, language, connections with territory, and political values" Moran $(2011,2155)$. The concept of national identity is complex and may belong to "a universe of illusions, distorted images, delusions" Dixson $(1999,130)$. Nations are now reliant on the collective imagination of the communities living within them (Boucher, 2009) and, also drawing on the ideas of Benedict Anderson, Turner (1994) points out 
that, as most people live in a modern, urban society, they never actually meet most of their fellow citizens, meaning that the common identity between individuals in indeed 'imagined'. If national identity is elusive, then it can be created through a variety of media and will be influenced by those in privileged positions, popular culture, and the nation's history. Or, as Hobsbawm (1999: 143) claims, it is the "sportsmen representing their nation" that are the primary expressions of these imagined communities.

The concept of 'nation' is historically very young, peaking after the/World War I (Hobsbawm, 1990). It is, therefore, not unlikely that many of the notions associated with national identity are rooted in early twentieth century ideals and narratives. These narratives become deeply ingrained in national culture and can, in particular, be reinforced by heroised figures. If it is indeed constructed, then it is possible for this idea to be re-modelled and managed, and for a collective interpretation of national identity to be developed, often based on existing, historical narratives, traditions and common myths (Smith 1991). Over time, the mythical elements in these narratives become accepted by a nation and solidified in popular culture.

Significantly, nations and their associated concepts such as national identity are dual phenomena, constructed from above but which can only be understood from below, based on the interests and views of the ordinary people (Hobsbawn 1990). Given Australia's complex history, constructions of national identity have been particularly significantfor its population. White (1981) states that, while many nations go through a period of inventing national identity, Australia has long supported a whole industry devoted to informing Australians of who they are, and that a sense of Australian identity was first developed in the nineteenth century. Hudson and Bolton $(1997,1)$ argue that although "Australian national identity is entirely mythical, even fiction" it continues to be a significant concept. 


\section{Contextual background}

As Heroes are "emotional icons whose qualities match ideals embedded in the culture" (Holden 2012, 19), it is not possible to separate a study of sports heroes from a study of the society within which they exist. Thus, to gain a deep understanding of the process by which sport fans form their heroes, it is first necessary to gain a strong understanding of the context within which heroisation takes place.

In 2012 the Greater Western Sydney (GWS) Giants entered the Australian Football League (AFL) as its 18th team. The AFL is the best supported sport competition in Australia in terms of average match and weekly attendance figures, with Stewart $(2005,112)$ describing it as Australia's "prenier) sports competition". AFL teams continue to retain links with specific suburbs and their associated identities, and the fans of these clubs have identifiable club cultures (Walsh 2015). Although Australian football can be a site for the construction of local, regional, and national identities, it has also been subject to negotiations and struggles for power and acceptance. It has, at various stages, accepted the involvement of a variety of different cultures (even actively encouraging young Irish Gaelic (amateur) football players to take up the sport (Nadel 1998)), which in turn have exerted their influence over the sport. The involvement and acceptance of non-British migrants from Europe was a gradual process, but it is now common to find players with European heritage playing in the AFL. There is also evidence for a long involvement by Aborigines (Gorman 2012; Gorman et al. 2015) and the AFL brand has "closely aligned itself with the politics of Aboriginal reconciliation" (Judd \& Butcher 2016, 69).

The establishment of this team afforded an unusual opportunity to research the formation of heroes within a complex, rich, socio-cultural context. The Giants entered 
the elite Australian Football League and were based in a region with no history of engagement with Australian football. The team was largely made up of young, relatively unknown players in the first instance and, as was widely predicted by most commentators in the media, finished their first season in last place, having won only two games in 2012. In their second season, they won only one game and again finished last. With the addition of several seasoned players, their results improved, and the Giants ended the 2014 season with a total of six wins, in sixteenth place. Byt their fourth year in 2015, GWS reached 11th place and won half of their regular season games. They are now an established team, typically challenging for honours but in their formative years there were fewer significant individual performances. This study aims to identify how heroic narratives are developed, particalarly when on-field success is lacking, to provide an understanding of hero formation.

While it was assumed that a participant observation approach would provide evidence of observable acts of devotion at games this was not the case. Observations at Giants' games and events revealed very little on heroisation, negligible large-scale obvious adoration of players by the fans, and few performative expressions of fandom. In the initial stages, the Giants' players were homogeneous in appearance and profile, with little playing experience, and were 'on the end' of some very one-sided scorelines. These factors were not conducive to individual players standing out from their peers and then being heroised. A lack of interaction between fans and players during games, and a resultant absence of observable heroisation, were also not aided by the small crowds at events and home matches. The paucity of fans would result in little recounting of the heroic deeds of players and ultimately slowed the process of heroisation.

\section{Methodology}


To gain an understanding of the narratives surrounding the Giants' players and staff, a netnographic approach that encompassed a number of virtual spaces and methods of analyses was utilised. Netnography offers a contemporary approach to data collection that allows the researcher to take part in online fieldwork in order to study cultures and communities and their interactions in virtual spaces (Kozinets 2015). Although Kozinets (2015) argues for participation in the online community, a complete observational, passive and unobtrusive method was chosen, a move adopted in a variety of earlier studies (Costello, McDermott \& Wallace 2017). The role of 'lurker' within virtual space was adopted as an active viewer rather than a contributor to the discussion.

Data collection took place throughout 2012 to 2014/and was obtained from three primary sources 1) e-mail correspondence from the clab to fans (including text and images); 2) media reports from two leading newspapers; and 3) information from fan interaction within two social media communities or fan forums. Two fan forums were identified as being the most commonly used sites for AFL-related discussions. The first forum, hereafter Forum A, in addition to having a specific section for the Giants, also had threads (collections of posts discussing a topic, typically presented in chronological order) for every player to have played for the club and the coaches. The threads for a number of key individuals (see below) proved the initial starting point for analysis of fan-generated discussions. In addition, 1084 threads within the main Giants-related forum were searched for references to the key individuals. A total of 170 threads were searched on the second forum, hereafter Forum B, which also had a specific GWS Giants page.

Ethical clearance was obtained for the research project prior to the study beginning. Bertilsson (2014) says that unobtrusive netnographies enables a researcher to avoid a number of ethical difficulties. Given that the forums did not require registration 
to access them, the topics being discussed were related to Australian football and so not judged to be of a sensitive nature, and there were a large number of posts and users, I deemed these forums public spaces (Eysenbach \& Till 2001), and that informed consent was not needed for such a passive analysis of retrospectively posted messages.

Miles and Huberman (1994) suggest that there are three generic stages to qualitative data analysis; data reduction; then data display; and conclusion drawing/verification (interpreting the findings). A progressive three-stage data coding procedure was utilised (Gobo 2008). This process consisted of deconstruction (open coding), construction (axial coding), and confirmation (selective coding). Data collection took place at all three of these stages and formed part of a spiral reflexive process, situated between sampling and analysis (Gobo 2008). At each stage of coding, data collection served a different purpose, first to uncover the conventions by which the observed interactions were bounded; second (during the construction stage) to explain the interactions; and finally, to document the ideas detailed during the confirmation stage. Data from all sources were first read through and notes were made with initial comments and ideas. These notes were then transformed into initial themes, which were refined and developed through further analysis and during subsequent stages of data collection (Rapley 2011).

Three key figures - Israel Folau, Jeremy Cameron, and Kevin Sheedy - stood out in this period as prominent individuals. Folau, a former rugby league player of Tongan heritage, was 'headhunted' to be a hero and was utilised in marketing and promotional material before he left the club at the end of the 2012 season. Cameron was a young player who emerged as the leading performer for the team, featuring frequently in the media. His on-field performances were recognised as significant by his peers, the media, and the wider FL community. Finally, Sheedy was the club's first coach and is 
one of Australian football's best-known figures. He is often divisive and was, at times, controversial. Findings on the three key heroes will be detailed in the following section, identifying the role of mythology in each of these narratives and the implications beyond these three individuals.

\section{Results}

Israel Folau was presented to the fans of the GWS Giants as a ready-made/hero, based primarily on his previous performances and standing in rugby league. However, he was not able to perform at a suitable athletic level during his time at the Giants and he failed to achieve even one significant personal success on the field. But he was at the forefront of marketing activities and received considerable media attention following his move from Australia's elite men's rugby league competition, the National Rugby League (NRL). Although it has been claimed that publicity is one of the most important factors in hero formation (Radford 2005), analysis revealed that the degree of media coverage in this instance was detrimental to the heroisation process. The substantial media attention served to hightight the obvious discrepancies between his supposed, (topdown, heroised) abilities and his actual on-field performances. The disjuncture between these two leyels of performance featured prominently in fan discourses of Folau and, in light of his high salary and his admission that he had never watched an Australian football match, resulted in him assuming a mercenary profile:

I've lost all respect for him after that comment. I realise he's going to be payed a small amount of the $\$ 1$ million a year on playing footy, but that's just plain ridiculous. (ForumB, post \#5)

What a dud! He's just in it for the cash I reckon. (ForumB, post \#10) 
He doesn't care!! As long as the $\$ \$ \$$ gets to his back pocket he'll be happy. It's crap that he is playing in this case though!! (ForumB, post \#12)

His prominent marketing role was also identified as a significant factor in both media and fan-generated narratives surrounding him. While AFL fans celebrated Folau's switch from a rival footballing code, and initially venerated him, the pro-NRL, Sydney print media saw his move as a betrayal (Parry 2013). He was further villainised when he left the Giants prematurely and switched to playing rugby union:

Izzy [Folau] just continues to lose his credibility. I'm sure he was reported to have told Parramatta [NRL team] he was $100 \%$ signing with them. Now he backflips and joins overseas rugby? He left NRL for a sport he's never played and ended up leaving. He's now going to another sport he never played. Will he last as long in union as he did in AFL? You can't tell me money has no influence on his decisions. Just the way Isee it. (ForumA, post \#52)

This villainisation is not surprising because, as is the case in other fields, heroised athletes can lose their status and assume the role of a villain when they turn their back on their followers and 'betray' them by leaving the club. The 'betrayer' is subsequently abused and faces psychological (and potentially physical) dangers before overcoming these obstacles to 'move on' and be heroised by their new club's followers. Such a 'journey' is immediately reconcilable with Campbell's (2004) concept of the heroic monomyth. Folau was also not successfully associated with a recognisable and established heroic pattern. Instead, his dominant narrative was largely based on the commodification of his body and his ability (and desire) to sell his sporting talent. Furthermore, as my colleagues and I have argued previously, Folau, due to his Tongan background, was frequently portrayed as a racialised 'other'; which had an impact on 
his acceptance by the dominant Anglo-Celtic AFL culture (Parry, Cleland \& Kavanagh 2019).

A mercenary nature is neither associated with Australianness nor with heroic ideals but could be equated with villainy. AFL fans, in addition to NRL fans, villainised him because he prioritised personal gain ahead of loyalty to a code and an associated passion for playing Australian football. Thus, Folau failed to conform to some of the ideologised concepts associated with competitive team sport and, therefore, falls outside of accepted heroic narratives.

Jeremy Cameron, on the other hand, was referred to as a'star' by the club, the media, and the AFL. This is a term associated with a compodity-celebrity status that is based on 'well-knownness' (Smart 2005; McKay \& Brooks 2013). The sports-world makes frequent use of this term to describe top athletic performers, with 'stars' typically differentiated from 'heroes' by both their prevalence and the lack of durability of their achievements. The media and sports leagues/teams, rather than fans, drive the term, and a star athlete may not be heroised (as was found to be the case with Folau). While the media and fans alike villainised Folau, Cameron was to emerge as a hero for the club's fans and, based on online forum data, more generally for Australian football fans:

How good is this young man. It defies logic that he only started playing Aussie Rules when he was 15 years old. (ForumA, post \#15)

[X] ot many blokes almost win the coleman ${ }^{1}$ [sic] in their second year and bag 90 goals in their first two seasons. (ForumA, post \#20)

Even as a Collingwood supporter, I freaking love him. I'm half convinced to buy a GWS jumper with his number on it. (ForumA, post \#8)

\footnotetext{
${ }^{1}$ The Coleman Medal is awarded to the top goal kicker in each regular season.
} 
Two fans went further still and expressed their adoration in rather colourful ways as follows:

Is it wrong that I want jezza [Cameron] to impregnate my missis? Them genes. (ForumA, post \#21)

and:

I just compared to my wife his resigning to how I felt when I proposed. (ForumA, post \#23)

His heroisation was, in part, based on pre-existing mythological hero patterns that can be found outside the sport world, and also drew on his association with notions of Australianness. Narratives surrounding Cameron emphasised the heroic journey that his sporting career has taken, reflecting Joseph Campbell's concept of the monomyth. Although his initial heroisation was based on his ability, this study reveals that athletic aptitude alone is not sufficient to form ahero.

Cameron was also presented in a manner that accentuated his body and physique, displaying his strength and athleticism and, ultimately, his masculinity. The traditional AFL playing kit, with its relatively high-cut shorts and sleeveless guernseys, emphasises players, bodies and allows leg and arm muscles to be displayed. Cameron's presentation by both the club and the media was reminiscent of earlier constructions of Anglo-Celtic Australianness. 


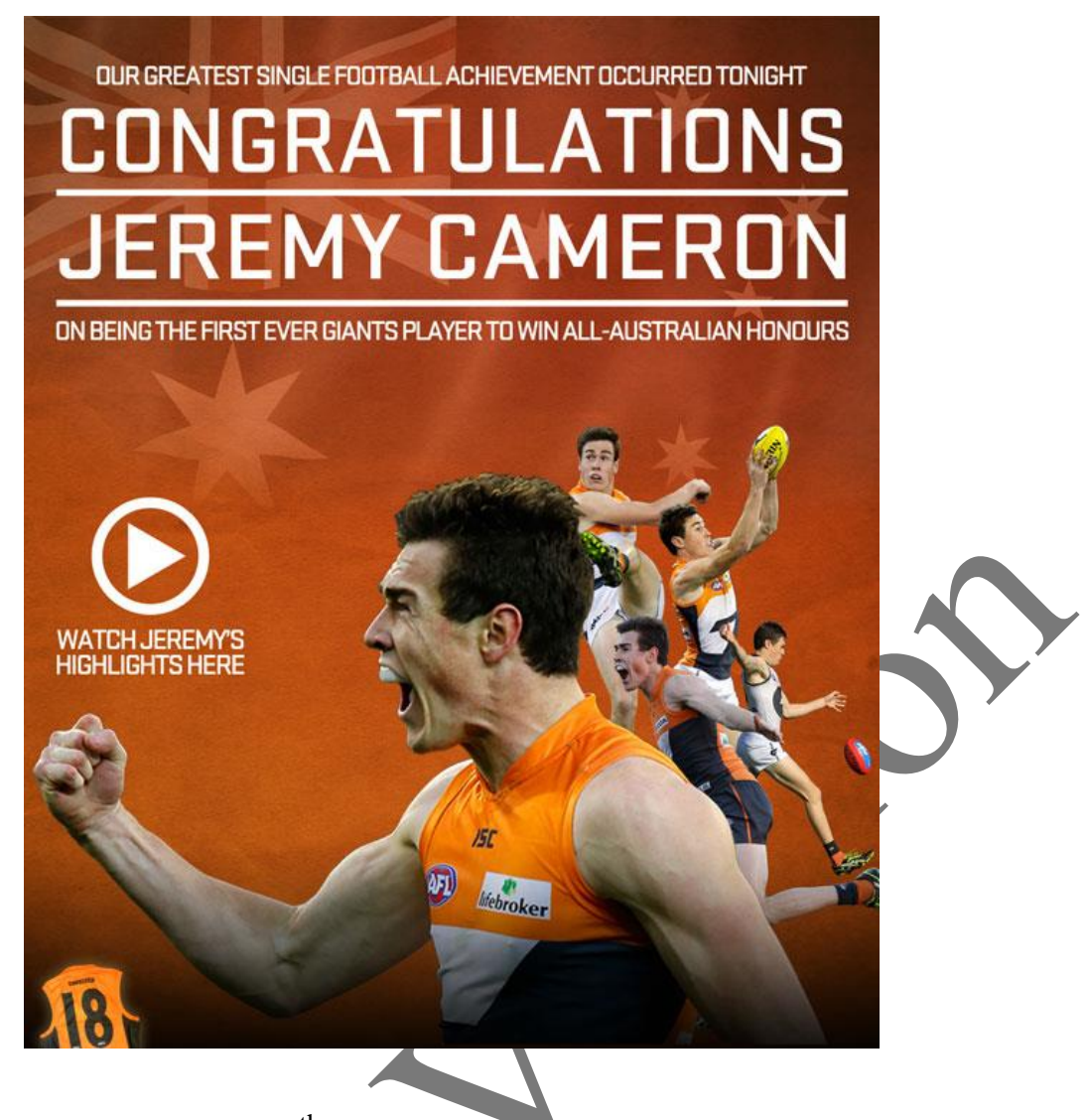

Figure 1. GWS Giants Email image $16^{\text {th }}$ September 2013

He fits with a traditionalAnglo-Celtic image of Australian footballers and thus serves to reinforce dominant attributes of Australian national identity. Traditional 'Australian' sports have been, and continue to be, dominated by a White hegemony (Gemmell 2007, Hallinan, and Judd 2009a), with Australian football historically seen as being the sport of White Australia. Therefore, in contrast to Folau, it is more palatable for fans to accept the Anglo-Celtic Cameron as an AFL hero because he fits with the traditional image of AFL players. A combination of his talent, Australianness, and the construction around him of heroic narratives that reflect and reinforce mythological hero patterns, create an almost exemplary heroic profile.

Cameron was not the only heroic figure at the club and, as sports coaches are selected as heroes in their own right, it is not surprising that the initial coach of the Giants, Kevin Sheedy, emerged as a hero. Coaches are often exposed to the public 
through the media (Miller 1990) and, in a world where institutionalised sport has taken on a quasi-religious status (Brody 1979), the coach may assume the role of a messianic figure. This status certainly applies to Sheedy, whose profile at the Giants reflected that of an inspiring leader tasked with conquering Western Sydney for the AFL. He was perceived as a 'great man' due to his historical achievements within the game. This significant reputation paired with his support of, and alignment with, 'traditional' Australian institutions and attributes, lead me to conclude that he fits the profile of a hero.

Sheedy's heroisation is largely based on his history in the AFL and unprecedented achievement of being involved in 1000 games (see below). While he was at GWS as coach he was its best-known figure, and his association with Australian football and Australian national identity provided the newly formed Giants with a degree of credibility and allowed them to associate themselves with the traditions of the sport. Sheedy's links to historical images of Australia, such as the military (Curthoys 1997) and working-class ideals (Leach 1997), further served as points of attachment for potential. He was signed to raise the profile of the club and presented as a hero for the Giants' fans. In this sense, he was a top-down, imposed hero, but even though he failed to have on-field success a combination of his charisma, longstanding/great achievements in the game, and ability to generate local pride meant that he was accepted by fans as a hero.

1000 games, an unbelievable milestone. Will anyone match it you think. (ForumA, post \#8)

You never say never (about anyone reaching a record), but some records like...this one, really do look almost unattainable. And Sheeds can still add some 25 games to it. (ForumA, post \#11) 


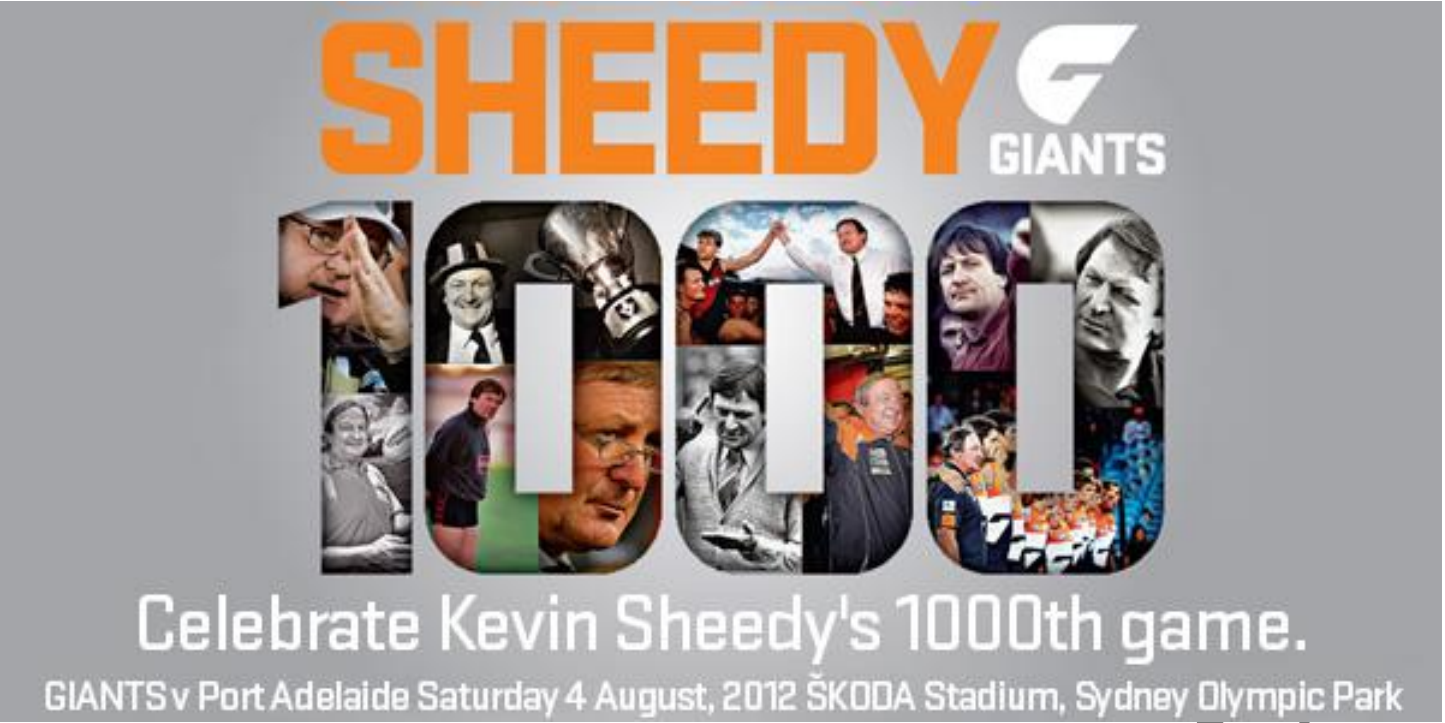

Figure 2. Email image $11^{\text {th }}$ July 2012

Narratives that focussed on his history and achievements were built up by the club and the media, and evoked feelings of nostalgia and "collective memory" (Griggs, Leflay \& Groves 2012, 90) amongst fans of AFL (See Figure 2). However, feelings and memories such as these are selectively recalled (Kohe 2010) and have created the legend of Kevin Sheedy. Prior (1995), in his biography of Sheedty, states that there are many legends and suburban myths about him, and it is common in the case of heroes for a mythical interpretation to develop. This mythical interpretation of heroes is termed "legend building"(Klapp 1949, 60), and much of what is 'known' about Sheedy is, therefore, mythologised.

Despite Sheedy's apparent alignment with tradition he also emerges as a complex, polarising and controversial character. His deliberate attempts to rile rival teams were, in part, designed to raise awareness of his new team and, although there is evidence that some observers recognise the intentionality behind his comments, he was derided by some fans, as shown here: 
He acts like a senile old coot in the media and people believe it. He did the same thing at Essendon and he wasn't a senile old coot then. (ForumA, post \#11)

Sheedy's terrible, I honestly cringe whenever I read a statement of his in the media. But he's creating headlines and 'controversy'; which is his job in all honesty. As for this statement he has made a completely unfounded accusation, which he's prone to do, he probably couldn't think of anything more controversial to say. (ForumA, post \#5)

Sheedy is a tosser of the highest order. I'm quite convinced he doesn't kyow what planet he is on. What planet he does think he is on is one where he is a deity and everything he says is taken as gospel. Truth is that no one cares what you do/say/think Sheeds. STFU [shut the fuck up] and retire already. You're an embarrassment. GWS needs a good coach for the modern era. Not some washed up old fossil. (ForumA, post \#6)

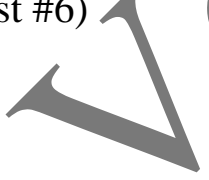

Sheedy's views were often based on very traditional constructions of regional and national identity, which may have contributed to the antipathy felt towards him by some fans on online forums. However, he fits with the larrikin ${ }^{2}$, a commonly heroised Australian archetype who shuns authority and stands up to social superiors or oppressors; which has becone another enduring Australian myth (Basu 2012; Whitman 2013). This character earlier heroic archetypes, principally the clever hero, and it is not uncommon for this figure to court controversy at times. Mythical heroes such as Robin Hood were frequently associated with villainous behaviour and, in a similar manner, Sheedy was at times portrayed as a villain or fool. Significantly this villainous or foolish behaviour is forgiven when it is aimed at social or physical oppressors, and it is within this context that Sheedy operated. Underlying many of his controversial comments was

\footnotetext{
${ }^{2}$ A term referring to irreverent yet cheeky behaviour.
} 
his attempt to position his fledgling team as battlers (see below). Therefore, Sheedy still maintained his heroic status even amidst controversy.

“They [the Sydney Swans] don't know how we play, we know how they play...They are a good side, they have been in finals most of the last decade but they still don't know how to play us because they have never played us. It just might be a little different tomorrow night. They have some very good young players themselves, obviously they are more experienced than us, but the excitement of youth and the energy - you just never, never know? (Sheedy, quoted in Cowley 2012, 10)

The narratives that were built up around Cameron and Sheedy assumed increased significance because their team was struggling on the pitch. The initial lack of on-field success meant that there were few heroic exploits for fans to associate with, and consequently few observable signs of heroisation emanating from the fans. Cameron's heroisation evolved gradually as his performances became indicative of his ability. Therefore, the process of hergisation first requires the development of narratives around the player and will, therefore, take time to become established.

\section{Discussion}

From each of these cases it becomes evident that the narratives constructed around them assumed pore importance than their actions. Heroic tales have existed for centuries and modern sport is one of the primary domains for the (re)creation of heroes (Parry 2009). As a result, these findings speak to the broader context within which sporting heroes operate. They are tied to national identity and the associated myths and stories that are deeply embedded within society. These stories then help to define collective and 
individual identities. In the case of Australian sports heroes, they express the fundamental themes of the myth of Australianness.

Sport plays a significant role in Australian society, and international sporting success remains a key element of national identity (Ward 2010). In the mid-twentieth century, the view of the 'typical Australian' was that of the Anglo-Celtic 'mate', a lineage stemming from the bush battlers, pastoral workers and diggers ${ }^{3}$-- heroic figures that embody masculine struggles against adversity (Saunders 1998). These heroic figures have been portrayed in ways that emphasise their masculine attitudes and behaviours and glorify their muscularity. This is the case with Jeremy Cameron. Thus, both sport and heroes serve to reinforce selected values that are deemed to be national representations in various discursive contexts. Yet as Hobsbawm (1983) identifies, traditions and national identities are typically based on a (fairly recent) historic past, often dating from the early twentieth century. It is these values that are typically strengthened.

This value reinforcement is certainly the case for the two identified heroes: Cameron and Sheedy. The notion of the 'boy from the bush' or the 'country boy' is indeed a historical image that carries cultural capital. It has featured prominently in the narratives around many Australian athletes, such as Don Bradman, cricketer Phillip Hughes, and now Jeremy Cameron. These Australian country/bush myths are not just confined to sport but are common within many aspects of Australian culture (Tucker 2005). While this form of myth is a quintessentially Australian concept, the basic narrative can be equated with wider pre-existing hero myths. The image of a young boy (often from an unpromising, and in this case country setting) who sets out on a journey

\footnotetext{
${ }^{3}$ Diggers is a common term for Australian and New Zealand soldiers
} 
of discovery to face trials and returns triumphant, has been perennially popular (Campbell 2004). However, for Campbell's (2004) monomyth narrative to be complete, the 'hero' does need to return to his home (to the benefit of the community). The boy from the bush narrative encapsulates this element of the heroic journey, yet it is also a reflection of the figure of the Cinderella/unpromising hero. Therefore, it not only has historical and cultural significance in an Australian setting, but also is applicable to the wider canon of work around heroisation.

The larrikin Australian (encapsulated by Kevin Sheedy) isnot simply part of the Australian narrative but belongs to universal accounts of heroes. The 'clever hero' captures these specific Australian and more general mythological aceounts and has been described as the triumph of brain over brawn (Klapp 1954a). This hero type is not against creating controversy but often offsets potential offence through the use of humour and wit. Sheedy fits this narrative construct.

If society is a reality 'sui generis' as Durkheim (1965) argues, then it exerts an influence over each individual, shaping his or her views and thoughts. Therefore, while stories relating to heroes are some of the key narratives that are present in sport, they will be shaped by the collective beliefs and the familiar patterns that are present in each society, sedimented in the unconscious of that culture. Thus, heroes facilitate cultural identification for large numbers of the population, emphasising the traditional values and norms of the dominant social classes, and acting as agents of social control by encouraging the emulation of their pro-societal behaviours (Klapp 1954b; Chung 2003). As a result, they serve to reinforce national identity, speaking to the documented myths of a culture. Research into modern sports heroes can identify patterns that reflect the hero (and villain) types in the narratives that are constructed around athletes. In each 
instance, it is possible to connect the three case studies with existing traditional or mythical heroic types.

Drucker and Cathcart (1994) have argued that hero types are not consistent across all cultures, and what is considered heroic will vary depending on the culture and the period. The evidence presented here supports claims for the universality of the phenomenon of hero myths, but heroisation is demonstrated to be sport specific and deeply influenced by socio-cultural context. It is the heroic narrative created around a player that allows them to achieve hero status rather than their athletic performances. This narrative will be influenced by dominant societal norms and cultural values but a suitable level of athletic ability or sporting success (such as in the case of Sheedy) is required to support heroisation.

Mythology is integral to discussions of both (Australian) national identity and heroisation. Bell $(2003,66)$ introduces the term mythscape to identify "the temporally and spatially extended discursive realm wherein the struggle for control of peoples [sic] memories and the formation of nationalist myths is debated, contested and subverted incessantly". While sport is not explicitly identified by Bell, cultural areas are frequently used to shape or manipulate myths of national identity (Donoghue \& Tranter 2018). Oriard (1982) claims that sport may even have been the sole repository of myth in late-twentieth-century American society. Either way, hero myths are universal, with scholars tracing them across different cultures and times and finding similarities in the patterns that were present in their narratives (see above). Some of the subjects of these earlier studies may be mythical characters, but it is also important to recognise that the stories built up around factual individuals can be altered to fit with existing mythological narratives of heroes. These archetypes are significant as they may be 
"modified to suit new needs" (Burke 2009, 202), and so they offer useful patterns for the analysis of modern athletes and potential heroes.

\section{Conclusion}

Myths are deeply ingrained in Western society and depict an 'everlasting' pattern (LéviStrauss 1955) as it is claimed that, once they become established, they tend to be resistant to revision. Details relating to contemporary heroes are often altered to ensure that they fit with recognised myths and narratives, blending factual elements with fictional ones. In the instance of a new sports club, if their players do not have an established playing career or traditions that appeal to fans for if fans of the club are yet to emerge), then hero formation will be the resutt of a lop-down process that is driven by the club and, in particular the media. Yet, to be heroised an athlete must fit the aforementioned imagined hero 'shape' that has been created within a particular society by already existing hero myths and traditions associated with national identity. For instance, if the imposed 'hero' does not have the requisite ability or does not conform to the 'dominant culture' of the team or sport, then the imposition will not be successful. An established sporting hero may be more easily imposed if they do correspond to the 'shape' of heroes inya particular sport or cultural environment. This examination of sports heroes, therefore, not only contributes towards the sociology of sport but to the wider field of sociology.

Sports heroes should, therefore, be considered in relation to broader mythological sporting narratives and representations of dominant modes of national identity. Indeed, in the cases of Folau, Cameron and Sheedy, heroes uphold dominant narratives in the construction of national identity. Not only does heroisation draw upon and reinforce characteristics of national identity, but because national identity is 
historically rooted, heroes can also be positioned in the broader, universal narrative of global myths and ideologies found outside sport (and beyond the boundaries of particular countries). The (largely) twentieth century constructions of national identity has drawn on older, wider myths, which have included selected heroic narratives.

However, myths are not fixed or immutable, and it should be noted that heroisation is a fluid process. It is possible for a subject to move between hero and villain types (and potentially others), as is demonstrated by the examples of Kevin Sheedy and Israel Folau. Whereas Folau's movement fromohero to villain was unintentional, Sheedy deliberately manipulated his image, and was comfortable assuming behaviour associated with villainous and foølish types. He temporarily adopted nefarious qualities to serve a specific purpose, and thus the controversies that he caused are likely to be forgiven, enabling him to move between hero and fool at will.

Heroisation is, therefore, neither reliant on the deeds nor the physical characteristics of heroes. The key factor in the formation of heroes is the narrative that is developed around them; with these constructions tied to national identity, which will often draw upon earlier mythological hero stories. The hero 'script' is, therefore, portable and can be adapted to different societies, where these universal narratives are reproduced at national levels, and selectively incorporated into myths surrounding national identity. There are, consequently, a limited number of typologies for heroes to follow and fans will best affiliate to a hero when the narratives surrounding them are familiar and culturally relevant, associated with traditional constructions of national identity.

\section{Acknowledgement}


This paper is derived from the author's doctoral thesis: Parry, KD. (2017). The Bad, The

Good, and The Ugly: The Formation of Heroes within the Setting of a New Sports Team. Doctoral Dissertation. Western Sydney University.

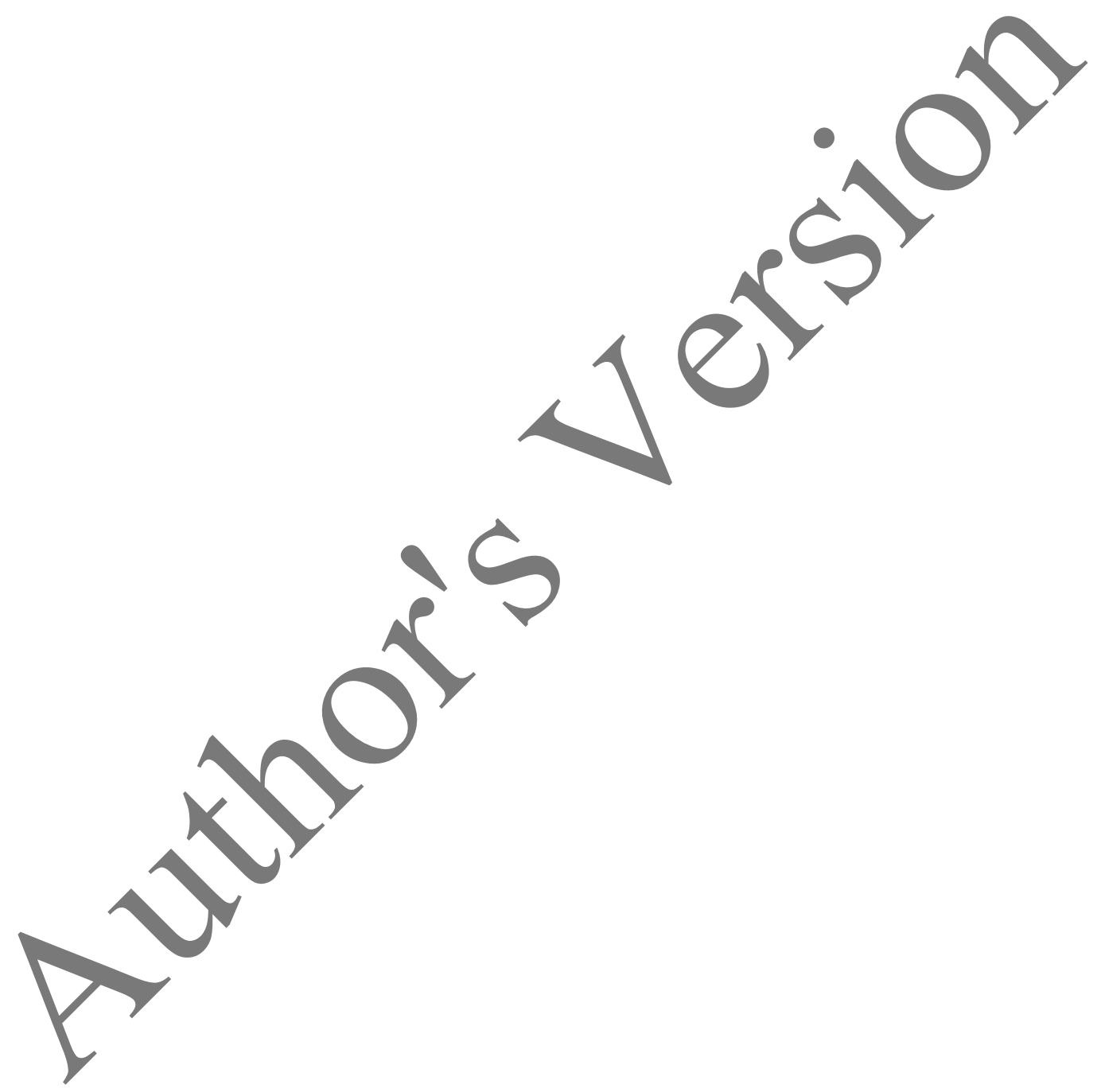




\section{References}

Allen, D. (2013). 'National Heroes': Sport and the Creation of Icons. Sport in History, 33(4), 584-594. doi:10.1080/17460263.2013.850782

Bale, J. (2006). How Much of a Hero? The Fractured Image of Roger Bannister. Sport in History, 26(2), 235-247.

Basu, L. (2012). Ned Kelly as memory dispositif : Media, time, power, and the development of Australian identities. Berlin: De Gruyter.

Beck, P. J. (2013). 'War Minus the Shooting': George Orwell on International Sport and the Olympics. Sport in History, 33(1), 72-94. doi:10.1080/17460263.2012.761150

Bell, D. S. A. (2003). Mythscapes: memory, mythology, and national identity. The British Journal of Sociology, 54(1), 63-81. doi:10.1080/0007131032000045905

Berger, P. L., \& Luckman, T. (1966). The Social Construction of Reality: A Treatise in the Sociology of Knowledge. London: Penguin Books.

Bertilsson, J. (2014). Critical netnography: Conducting critical research online. In E. Jeanes \& T. Huzzard (Eds.), Critical management research: reflections from the field (pp. 137-152). London: SAGE Publications.

Bolton, G. C., \& Hudson, W. (Eds.). (1997). Creating Australia: changing Australian history. St Leonards, N.S.W.: St Leonards, N.S.W. : Allen and Unwin.

Boon, K. A. (2005). Heroes, Metanarrative, and the Paradox of Masculinity in Contemporary Western Culture. The Journat of Men's Studies, 13 (3), 301 - 312.

Boorstin, D. J. (1992). The image : a guide to pseudo-events in America. New York: New York : Vintage Books.

Boucher, L. (2009). Trans/national history and disciplinary amnesia : historicising White Australia at two fins de siècles. In J. Carey \& C. McLisky (Eds.), Creating White Australia (pp. 44-63). Sydney: Sydney University Press.

Brody, M. K. (1979). Institutionalized Sport as Quasi-Religion: Preliminary CONSiDerations. Journal of Sport \& Social Issues, 3(2), 17-27. doi:10.1177/019372357900300203

Burke, P. (2009). Ropular Culture in Early Modern Europe (3rd ed.). Farnham: Ashgate.

Campbell, J. (2004). The hero with a thousand faces (2004 ed.). Princeton: Princeton University Press.

Carlyle, T. (1840). On Heroes, Hero Worship and the Heroic in History. London: Oxford Books.

Cashmore, E. (2004). Beckham (2nd ed.). Cambridge: Polity.

Cathcart, K. S. (1994). From Hero to Celebrity: The Media Connection. In S. J. Drucker \& R. S. Cathcart (Eds.), American heroes in a media age (pp. 36-46). Cresskill, N.J.: Hampton Press.

Chung, H. (2003). Sport Star Vs Rock Star in Globalizing Popular Culture: Similarities, Difference and Paradox in Discussion of Celebrities. International Review for the Sociology of Sport, 38(1), 99-108. doi:10.1177/10126902030381006

Coad, D. (2002). Gender Trouble Down Under: Australian Masculinities. Le MontHouy: Presses Universitaires De Valenciennes.

Cowley, M. (2012). Coach sold on Giants upset win, Article. The Sydney Morning Herald (Sydney, Australia), p. 10. Retrieved from http://ezproxy.uws.edu.au/login?url=http://go.galegroup.com.ezproxy.uws.edu.a 


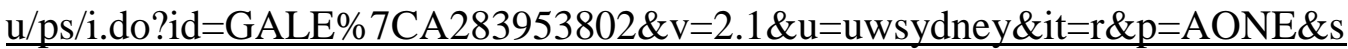
$\mathrm{w}=\mathrm{w} \& \mathrm{asid}=0 \mathrm{eec} 6 \mathrm{dad} 816 \mathrm{cc} 0 \mathrm{ab} 8670115 \mathrm{de} 69220 \mathrm{f} 2$

Crawford, G. (2004). Consuming Sport: Fans, Sport and Culture. London: Routledge.

Crepeau, R. C. (1981). Sport, Heroes and Myth. Journal of Sport \& Social Issues, 5(1), 23-31. doi:10.1177/019372358100500103

Curthoys, A. (1997). History and Identity. In W. Hudson \& G. Bolton (Eds.), Creating Australia: Changing Australian History (pp. 23-38). St Leonards: Allen \& Unwin.

Dixson, M. (1999). The Imaginary Australian: Anglo-Celts and Identity. Sydney: UNSW Press.

Donoghue, J., \& Tranter, B. (2018). On Bradman's bat: Australian sporting heroes. National Identities, 20(2), 143-156. doi:10.1080/14608944.2016.1168792

Drucker, S. J., \& Cathcart, R. S. (Eds.). (1994). American heroes in a media age. Cresskill, N.J.: Hampton Press.

Durkheim, E. (1965). The Rules of Sociological Method (S. A. Solovay \& J. H. Mueller, Trans. G. E. G. Catlin Ed. 8th ed.). New York: The Free Press

Eysenbach, G., \& Till, J. E. (2001). Ethical issues in qualitative research on internet communities. BMJ, 323(7321), 1103.

Fisher, W. R. (1984b). The Narrative Paradigm: In the Beginhing. Yournal of Communication, 34(1), 74-89. doi:10.1111/j.1460-2466.1984.tb02986.x

Gemmell, J. (2007). All White Mate? Cricket and Race in Oz. Sport in Society, 10(1), 33-48. doi:10.1080/17430430600989118

Gobo, G. (2008). Doing ethnography. London: SAGE.

Gorman, S. (2012). Voices from the boundary line: the Australian Football League's Indigenous Team of the Century. Sport in Society, 15(7), 1014-1025. doi:10.1080/17430437.2012.723371

Gorman, S., Judd, B., Reeves, K., Osmond, G., Klugman, M., \& McCarthy, G. (2015). Aboriginal Rules: The Black History of Australian Football. The International Journal of the History of Sport, 32(16), 1947-1962. doi:10.1080/09523367.2015.1124861

Greenwood, P. B., Kanters, M. A., \& Casper, J. M. (2006). Sport Fan Team Identification Formation in Mid-Level Professional Sport. European Sport Management Quarterly, 6(3), 253-265. doi:10.1080/16184740601095016

Griggs, G., Leflay, K. \& Groves, M. (2012). "Just Watching It Again Now Still Gives Me Goose Bumps!": Examining The Mental Postcards of Sport Spectators. Sociology of Sport Journal, 29(1), 89-101. Retrieved from

http://ezproxy.uws.edu.au/login?url=http://search.ebscohost.com/login.aspx?dire $c t=$ true \&db=sih \&AN=74294462\&site=ehost-live\&scope=site

Hallinan, C., \& Judd, B. (2009). Race relations, Indigenous Australia and the social impact of professional Australian football. Sport in Society, 12(9), 1220-1235. doi:10.1080/17430430903137910

Hartman, K. L. (2014). Fields of Dreams and Gods of the Gridiron: The Trinity of Myth, Sport and the Hero. In D. Whitt \& J. Perlich (Eds.), Myth in the Modern World: Essays on Intersections with Ideology and Culture (pp. 165-184). Jefferson, NC: McFarland \& Company Incorporated Pub.

Hobsbawm, E. J. (1992). Nations and Nationalism Since 1780: Programme, Myth, Reality. Cambridge: Cambridge University Press.

Hobsbawm, E. (2012). Introduction: Inventing Traditions. In E. Hobsbawm \& T. Ranger (Eds.), The Invention of Tradition (pp. 1-14). Cambridge: Cambridge University Press. 
Holden, T. J. M. (2012). Media Made: The reinvention of athletes as Heroes, Stars, and Celebrities in Contemporary Japan. In C. Sandvos, M. Real, \& A. Bernstein (Eds.), Bodies of Discourse: Sports Stars, Media, and the Global Public.

Hutchins, B. (2002). Don Bradman: challenging the myth. Port Melbourne: Cambridge University Press.

Judd, B., \& Butcher, T. (2016). Beyond equality: the place of Aboriginal culture in the Australian game of football. Australian Aboriginal Studies, 2016(1), 68-84.

Klapp, O. E. (1948). The Creation of Popular Heroes. The American Journal of Sociology, 54(2), 135-141. doi:10.2307/2771362

Klapp, O. E. (1949). Hero Worship in America. American Sociological Review, 14(1), 53-62. doi: $10.2307 / 2086446$

Klapp, O. E. (1954a). The Clever Hero. The Journal of American Folklore, 67(263), 2134.

Klapp, O. E. (1954b). Heroes, Villains and Fools, as Agents of Social Control. American Sociological Review, 19(1), 56-62. doi:10.2307/2088173

Kohe, G. Z. (2010). Civic representations of sport history: the New Zealand Sports Hall of Fame. Sport in Society, 13(10), 1498-1515. doi:10.1080/17430437.2010.520939

Kozinets, R. V. (2010). Netnography: Doing Ethnographic/Research Online: SAGE Publications.

Leach, M. (1997). 'Manly, True and White': Masculine Identity and Australian Socialism. In G. Stokes (Ed.), The Politics of Identity in Australia (pp. 63-77). Melbourne: Cambridge University Press.

Lévi-Strauss, C. (1955). The Structural Study of Myth. The Journal of American Folklore, 68(270), 428-444. doi:10.2307/536768

Lucas, R. (1998). Dragging it out: Tales of masculinity in Australian cinema, from Crocodile Dundee to Priscilla, queen of the desert. Journal of Australian Studies, 22(56), 138-146.ddi:10.1080/14443059809387368

Maguire, J. A. (2011). Reflections on process sociology and sport: 'walking the line'. Sport in Society, 14(7-8), 852-857. doi:10.1080/17430437.2011.603537

McKay, J., \& Brooks, K.(2013). "Wayne's World": Media Narratives of Downfall and Redemption About Australian Football "King," Wayne Carey. In L. A. Wenner (Ed.), Fallen sports heroes, media, \& celebrity culture (pp. 236-250). New York: PAang.

Miles, M. B, \& Huberman, A. M. (1994). Qualitative data analysis : an expanded sourcebook (2nd ed.). Thousand Oaks, Calif.: Thousand Oaks, Calif. : SAGE.

Miller, T. (1990). The Dawn of an Imagined Community: Australian Sport on Film. Sporting Traditions, 7(1), 48-59.

Moran, A. (2011). Multiculturalism as nation-building in Australia: Inclusive national identity and the embrace of diversity. Ethnic and Racial Studies, 34(12), 21532172. doi:10.1080/01419870.2011.573081

Naha, S. (2012). Producing the First Indian Cricketing Superhero: Nationalism, Body Culture, Consumption and the C.K. Nayudu Phenomenon. The International Journal of the History of Sport, 29(4), 562-582.

Oriard, M. (1982). Dreaming of heroes: American sports fictions, 1868-1980. Chicago: Nelson-Hall.

Parry, K. D. (2009). Search for the hero: an investigation into the sports heroes of British sports fans. Sport in Society, 12(1), 212-226. 
Parry, K. D. (2013). Can't Buy Me Love: The Rise and Fall of an AFL “Hero". In D. Hynes, A. Kiernan, \& K. Parry (Eds.), Football and Communities Across Codes (pp. 15-24). UK: Inter-Disciplinary Press.

Parry, K. D., Cleland, J., \& Kavanagh, E. (2019). Racial folklore, black masculinities and the reproduction of dominant racial ideologies: The case of Israel Folau. International Review for the Sociology of Sport.doi:10.1177/1012690219860355

Pearson, C. S. (1989). The Hero Within: Six Archetypes We Live By (Expanded ed.). San Francisco: Harper \& Row.

Phillips, M. G., \& Osmond, G. (2009). Filmic Sports History: Dawn Fraser, Swimming and Australian National Identity. The International Journal of the History of Sport, 26(14), 2126-2142. doi:10.1080/09523360903303094

Prior, T. (1995). Sheeds: A Touch of Cunning. Melbourne: Wilkinson Books.

Radford, P. (2005). Lifting The Spirits Of The Nation: British Boxers And The Emergence Of The National Sporting Hero At The Time Of The Napoleonic Wars. Identities, 12(2), 249-270. doi:10.1080/10702890590950609

Raglan, L. (1956). The Hero: A Study in Tradition, Myth and Drama:Dover Publications.

Rapley, T. (2011). Some Pragmatics of Data Analysis. In D. Silverman (Ed.), Qualitative Research: Issues of Theory, Method and Practice (pp. 273-290). London: Sage.

Rojek, C. (2001). Celebrity. London: Reaktion.

Rojek, C. (2012). Fame Attack: The Inflation of Celebrity and Its Consequences. London: Bloomsbury Academic.

Saunders, K. (1998). 'Specimens of superb manhood:' The lifesaver as national icon. Journal of Australian Studies, 22(56), 96-105.

Smart, B. (2005). The Sport Star: Modern Sport and the Cultural Economy of Sporting Celebrity. London: Sage.

Smart, B. (2007). Not playing around: global capitalism, modern sport and consumer culture. In R. Giulianotti \& R. Robertson (Eds.), Globalization and Sport (pp. 627). Oxford: Blackwell Publishing.

Smith, A. D. (1991). National Identity: University of Nevada Press.

Stevens, J. A., Lathrop, A. H., \& Bradish, C. L. (2003). "Who is Your Hero?" Implications for Athlete Endorsement Strategies. Sport Marketing Quarterly, $12(2), 103-110$.

Stewart, B. (2005). Channeling passion or manufacturing identity? Managing fans in the Australian Hootball League. In M. Nicholson (Ed.), Fanfare: spectator culture and Australian rules football (pp. 109-124). Melbourne: Australian Society for Sports History.

Tännsjö, T. (1998). Is Our Admiration for Sports Heroes Fascistoid? Journal of the Philosophy of Sport, 25(1), 23-34. doi:10.1080/00948705.1998.9714566

Tirino, M., \& Bifulco, L. (2018). The Sports Hero in the Social Imaginary. Identity, Community, Ritual and Myth. Im@go. A Journal of the Social Imaginary, 11, 925. doi:10.7413/22818138110

Tucker, S. (2005). The 'country' in contemporary Australian women's country music: Gender, history, narrative. Journal of Australian Studies, 29(86), 111-118.

Turner, G. (1994). Making it national: Nationalism and Australian popular culture. St Leonards, N.S.W.: Allen \& Unwin.

Viita, O. (2012). A Reluctant Hero: Hannes Kolehmainen and the Politics of Sporting Fame in Finland. The International Journal of the History of Sport, 29(7), 9801000 . 
Wagg, S. (2007). Angels of Us All? Football Management, Globalization and the Politics of Celebrity. Soccer \& Society, 8(4), 440-458.

Walsh, M. (2015). Club Identity/Class Identity: Negotiations of Popular Memory by Followers of the Australian Football League. The International Journal of the History of Sport, 32(13), 1593-1610. doi:10.1080/09523367.2015.1120194

Wann, D. L., Melnick, M. J., Russell, G. W., \& Pease, D. G. (2001). Sport fans : the psychology and social impact of spectators. New York: New York : Routledge.

Whitman, K. (2013). The 'Aussie Battler' And The Hegemony Of Centralising Working-Class Masculinity In Australia. Australian Feminist Studies, 28(75), 50-64. doi:10.1080/08164649.2012.758026

Wright, W. (2005). Introduction: The Hero in Popular Stories. Journal of Popular Film \& Television, 32(4), 146-148.

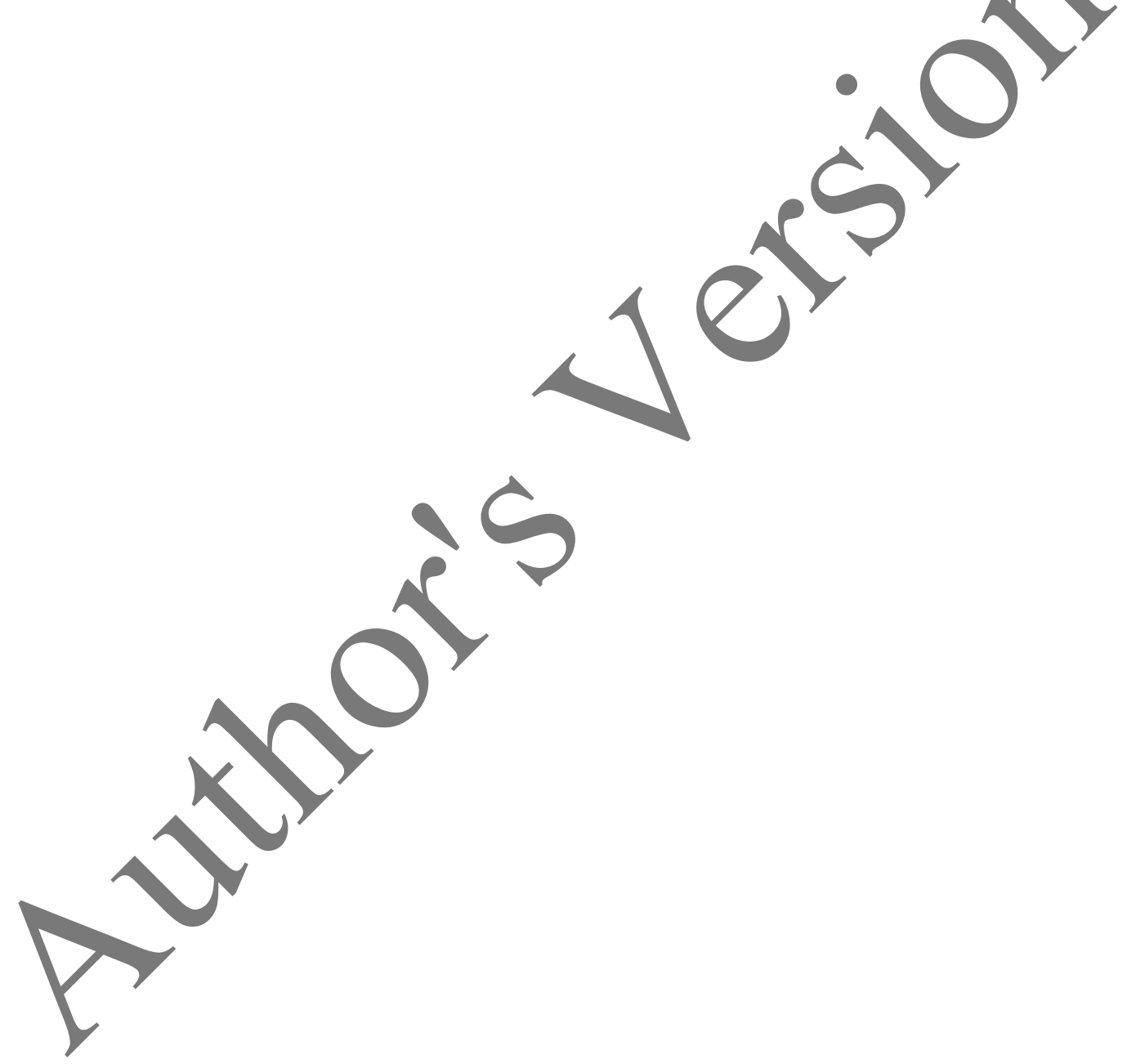

